\title{
The effect of Concept Cartoons to Academic Achievement in Instruction on the Topics of Divisibility
}

\author{
Abdullah Kaplan \\ Atatürk University, TURKEY \\ Mesut Öztürk \\ Bayburt University, TURKEY
}

•Received 18 December 2014•Revised 17 April 2015•Accepted 26 May 2015

The purpose of this study was compared to the effect of academic achievement of concept cartoons and activity based instruction in instruction on the topics of divisibility rules and prime number. The matching- only design, which is quasi experimental design, is used in this study. It is applied sixth grade $(\mathrm{N}=42)$ students at a middle school in Gümüşhane in autumn term in academic year 2012- 2013. Different two groups participate for this study. One of the groups is selected control group, which is used activity based teaching, and another group is experimental group, which is used instruction by concept cartoon. SPSS 16.0 packet program is used in the analysis of the data in this study. The first the test of the normality, within pretest and posttest, is applied and was founded that the data is suitable the normality. Then t- test is applied between pretest data for reveal whether different significant or not. ANCOVA is applied covariate pretest results to post test data. The study reveal that there was a significant difference in academic achievement between those students taught with the two methods in favor of concept cartoon which means those students taught by concept cartoon performed better than those taught with activity based instruction. The finding also shows that concept cartoon method is an effective method of teaching topics of divisibility rules and prime numbers.

Keywords: concept cartoons, divisibility rules, prime number, activity based instruction, mathematics education

\section{INTRODUCTION}

Education is an individual process; however its outcomes affect the whole of society. Programme for International Student Assessment (PISA), the aim to measure of skill and knowledge gain of children that fifteen ages in industrialized countries, have making compares to field which reading skill, science and mathematics literate between countries and cultural. In 2003 when prior to change to Turkish Educational System There was significant difference as the statistical

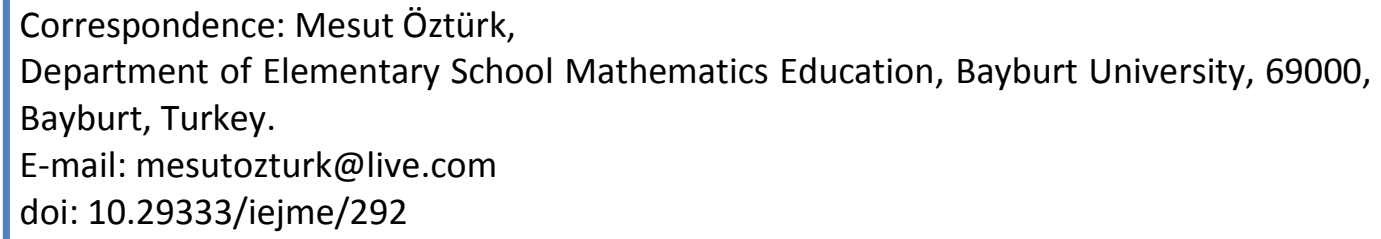


between Turkey and Organization for Economic Cooperation and Development (OECD) countries field that mathematics literate in made research and Turkey is less successful than OECD countries (EARGED, 2005).

Authorities must have appeared that don't successful of old education system in the past made studies and then Turkey is altering educational system and she recognizes constructivist approach. Turkey adopts active and meaningful learning strategies with this approach. Nevertheless, altered educational system couldn't have been affected that Turkey is 29st among participant 30 OECD countries in math literate in 2006 (EARGED, 2010a). This result didn't change in 2009, and Turkey is maximum 31st, minimum 32st with \%95 probability among participant 33 OECD countries in 2009 (EARGED, 2010b).

This results show that constructivist approach and active learning don't internalized, yet. Achievement will come when assimilate this approach. Active learning is construct own learner selves knowledge and skill their joint which active in learning environment. Learners acquaint which improve problem solved, skill easier than explain that own think in this approach that careful focus on learner (Kaplan, Öztürk, \& Ertör, 2013; Karamustafaoglu, 2009). Materials which uses in teaching process are important for obtain meaningful learning in the active learning strategy. One of the materials is concept cartoons (Birisçi \& Metin, 2010; Birisci, Metin, \& Karakas, 2010).

Concept cartoons, a type caricature, represent different consider about which a special concept and it make up for tree or five figure (Cengizhan, 2011; Ekici, Ekici, \& Aydın, 2007; Naylor \& Keogh, 1999). These figures should form misconceptions that are the number of figures ought to do as the number of misconceptions. Prepared concept map by students in application's result can better academic achievement of students. Its foundation based constructivist approach (Akamca, Ellez, \& Hamurcu, 2009) and it can organize learning all students which both small groups and large groups (Cengizhan, 2011; Sewell, 2002). Different studies show that concept cartoons affect or contribute to reading and thinking skill, to improve motivation, to acquaint of scientific knowledge, to flourish of scientific thinking and problem solved (Ekici, Ekici, \& Aydın, 2007; Şengül \& Üner, 2010; Stephenson \& Warwick, 2002).

Concept cartoons generally use in science and one, a teaching approach, present high level visual to student (Aydın, 2015). The subject is offered how conclude that different view in concept cartoons. Learner admits a think and it constructive own learning. Students are more relation easily between daily life and academic knowledge by concept cartoons (İnel, Balım, \& Evrekli, 2009; Morris, Merritt, Fairclough, Birrell, \& Howitt, 2007, s. 18; Şahin \& Çepni, 2011). In addition to concept cartoons is more easier work of teacher where class administration and with this way it help make up for own consider of students and hold their at the conclusion situation (Kabapınar, 2009).

Concept cartoons generally are used elementary education. Some humorous characters use in application of this approach. Prepared cartoons will supply familiar to daily life problem in future life of students. A character which it talks really life or it asks a question must be in prepared of cartoons. As well as there must be other represent characters that alternative views. Dialogs in cartoon help evolve sense which decides liberty of students. When teaching by concept cartoons, the first cartoons met students and then conclude right of knowledge on the cartoons and eventually right knowledge made up for outcome of conclude repeat assess on the cartoon. As if concept cartoons appear only as a tool help relation between students and teacher, but one really supply affect judgment to students (Balım, İnel, \& Evrekli, 2008; Birisci, Metin, \& Karakas, 2010; Cengizhan, 2011; Sexton, Gervasoni, \& Brandenburg, 2009). Concept cartoons can prepare as poster, work table and by computer (Birisçi \& Metin, 2010; Birisci, Metin, \& Karakas, 2010). 
Concept cartoon can use for instruction, as well as assess of teaching process, diagnosis of misconception and solve of misconception as a method which effective (Akamca, Ellez, \& Hamurcu, 2009, s. 22; Keogh, Naylor, Boo, \& Feasey, 2002; Ormancı \& Şaşmaz-Ören, 2011). Despite it is very used in science, it doesn't enough used math. But one prevents anxiety toward math, thrive academic achievement in math and it is used as modern and important a tool in solve of misconception (Kaplan, Altaylı, \& Öztürk, 2014; Kaplan, İşleyen, \& Öztürk, 2011; Sexton, Gervasoni, \& Brandenburg, 2009; Uğurel \& Morall, 2006). In accordance with Cengizhan (2011), there are three effect factors that they arrives successful made instruction by concept cartoon; the level of interaction within class, how much research of students and the role of teacher.

Despite concept cartoons affect in a lot of situation, its successful unexpected in a multi choice questions (Naylor \& Keogh, 1999). As the reason of this situation is show that put forward alternative prepared dialogs for offer different consider on the concept cartoon similarity multi choice tests, therefore there are risks make up for misconceptions. The number of study, however, shows that the use of concept cartoon contributes evaluation cognitive and emotional toward mathematics of middle school (Dereli, 2008; Şengül, 2011; Şengül \& Dereli, 2013; Şengül \& Üner, 2010; Üner, 2009).

Şengül and Üner (2010), make study on the topic of algebraic expression and equations in seventh grade and they compared to the effect of student's logical considering teaching by concept cartoon and traditional teaching. That study's result shows that there wasn't significant difference between groups.

Made a study with participate of third and fourth grade students by Sexton, Gervasoni and Brandenburg (2009), indicate that concept cartoon affect to flourish intelligence reasoning of students on the topic of used to operation skill.

The study that conducted by Şengül (2011), is measured self- efficiency toward mathematic of seventh grade students, use of concept cartoon reinforcement perception of students and it evolve interest of students toward math.

\section{The aim and the significant of the study}

Prime numbers and divisibility are fundamental subjects in the teaching of arithmetic and algebra (Altun, 2008). Thus, to learn this subject will be contributed and facilitated the learning of different subjects. For this reason, it is important to teach this subject in different teaching methods and to provide the meaningful learning. The purpose of this study was to investigate the effect of concept cartoon on the academic achievement of the students in the instructions of the topics of divisibility rules and prime numbers among the sixth grade students in the middle school, and it also investigated into which of the concept cartoon and activity based methods is better method of instruction.

1. There is no significant difference between in academic performance of students who were taught divisibility rules and prime numbers and those who were taught the same topic by activity based instruction.

2. There is no significant effect of concept cartoon method on the academic achievement in the instructions of the topics, divisibility rules and prime numbers.

This study is important to one lead to teacher. As well as it is weighty for academics, as one encourage to use material. In addition to, it direct for pre- service period teacher how it is specimen model that their course process in the future. 


\section{METHODS}

In this study is used the matching- only design that is one of a quasi-experimental design. There isn't randomly and one of the groups is selected experimental group and another is control group in this design. Pretest is used to groups and then applied teaching strategy is groups eventually posttest is used (Büyüköztürk, KılıçÇakmak, Akgün, Karadeniz, \& Demirel, 2010). Test application when prior to study and after the study constitute for more reliable than foresee affect in the study with used quasi experimental design (McMillan \& Schumacher, 2014). Different two groups participate for this study. One of the groups is selected control group, which is used activity based teaching, and another group is experimental group, which is used instruction by concept cartoon.

\section{Sample}

This study is applied at a middle school in Gümüşhane city in autumn term in academic years 2012- 2013. In choice of the sample of this study is selected with randomly method a middle school which among middle school in Gümüşhane city and then is elected with randomly method, control and experimental groups, two class among sixth grade in this middle school. Results of this choice there are $(\mathrm{N}=20)$ students in control group and $(\mathrm{N}=22)$ students in experimental group. The great sample in the small group working makes it difficult to control the variables. For this reason, in such studies the sample number of the groups to be above 20 can be acceptable (Corbetta, 2003).

\section{Data collection tools}

A question pool make up for by researchers during prepared of data collection tools. 25 multi choice questions are elected in this question pool applied. Selected questions are applied ( $\mathrm{N}=34)$ students in pilot application. Reliability coefficient KR20 of the test was found to be 80 . Five questions that increased reliability coefficient take out from test and then reliability coefficient KR-20 for remain 20 questions was founded .85. In accordance with Kayıs test with this level is high degree reliability coefficient. The aim to measure the validity of test prepares table of specification for target behavior and was taken consider of one teacher and three experts, therefore covered validity of test is supplied (Kayış, 2009). Distinguished according as objectives of questions are appeared Table 1.

\section{Data analysis}

SPSS 16.0 packet program is used in the analysis of the data in this study. The first the test of the normality, within pretest and posttest, is applied and was founded that the data is suitable the normality. Then t- test is applied between pretest data for reveal whether different significant or not. ANCOVA is applied covariate pretest results to post test data.

\section{Experimental process}

Table 2 is show that separate accordance as weeks of the applications or course process, activity based teaching and instruction by concept cartoon.

Table 1. Table of specification for target behavior

\begin{tabular}{ll}
\hline Objectives & The Numbers of Questions \\
\hline Multiplier and factors of natural number and prime number & $2,3,7,11,13,17$ \\
Explain to divisibility rule & $1,5,9,10,12,14$ \\
$\begin{array}{l}\text { Determined common divisor and common factors of natural number and } \\
\text { applied problem }\end{array}$ & $4,6,8,16,18,19,20$ \\
\hline
\end{tabular}


Table 2. Separated accordance to time of course process

\begin{tabular}{|c|c|c|}
\hline Period & Activity based instruction & $\begin{array}{l}\text { The instruction by concept } \\
\text { cartoons }\end{array}$ \\
\hline 1 & Pretest is applied. & Pretest is applied. \\
\hline 2 & $\begin{array}{l}\text { Activities which "Multipliers in the packed" within (Eden, 2011) } \\
\text { and "Multiplier of a natural number", "finding multipliers" within } \\
\text { (Göğün, 2010) realized. }\end{array}$ & $\begin{array}{l}\text { Teaching realized by concept cartoons as } \\
\text { Figure } 1 \text { in conclusion environment. }\end{array}$ \\
\hline 2 & $\begin{array}{l}\text { Activities which "The principal of divisibility", "Divisibility } \\
\text { by number 2", "Divisibility by numbers } 3 \text { and 9" within } \\
\text { (Eden, 2011) and "Constituting table, determining carts" } \\
\text { within (Göğün, 2010) realized. }\end{array}$ & $\begin{array}{l}\text { Teaching realized by concept cartoons as } \\
\text { Figure } 2 \text { in conclusion environment. }\end{array}$ \\
\hline 2 & $\begin{array}{l}\text { Activities which "Finding divisors", "Finding prime number", } \\
\text { "Finding different object", "Prime number" within (Eden, 2011) } \\
\text { and "make up for quadrangle square" within (Gögün, 2010) realized. }\end{array}$ & $\begin{array}{l}\text { Teaching realized by concept cartoons as } \\
\text { Figure } 3 \text { in conclusion environment. }\end{array}$ \\
\hline 2 & $\begin{array}{l}\text { Activities which "Common multiples", "Distinguish to squared" } \\
\text { within (Eden, 2011) and "Least common multiple" within } \\
\text { (Göğün, 2010) realized. }\end{array}$ & $\begin{array}{l}\text { Teaching realized by concept cartoons as } \\
\text { Figure } 4 \text { and Figure } 5 \text { in conclusion } \\
\text { environment. }\end{array}$ \\
\hline 1 & Posttest is applied & Posttest is applied \\
\hline
\end{tabular}

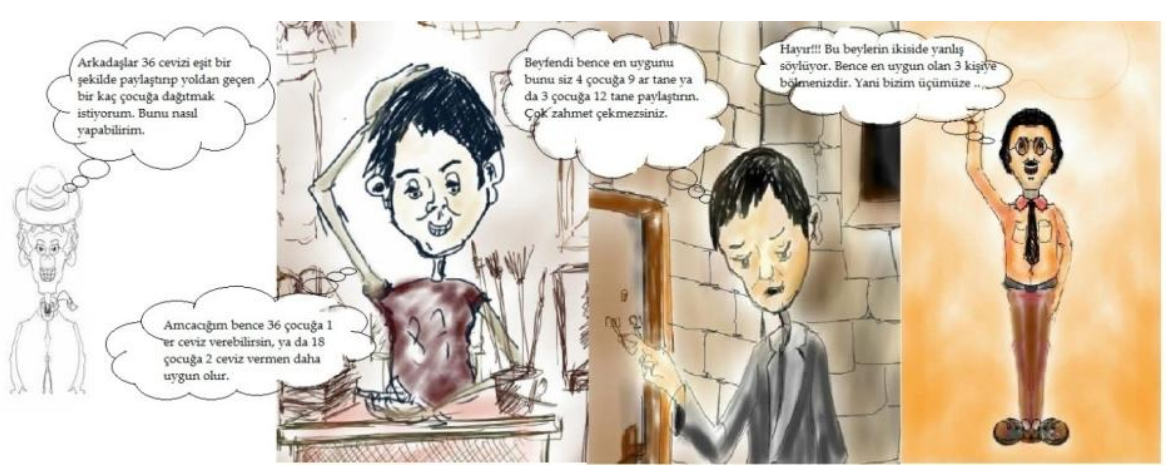

Figure 1. Instruction on the topic of multiplier of a sample of cartoon

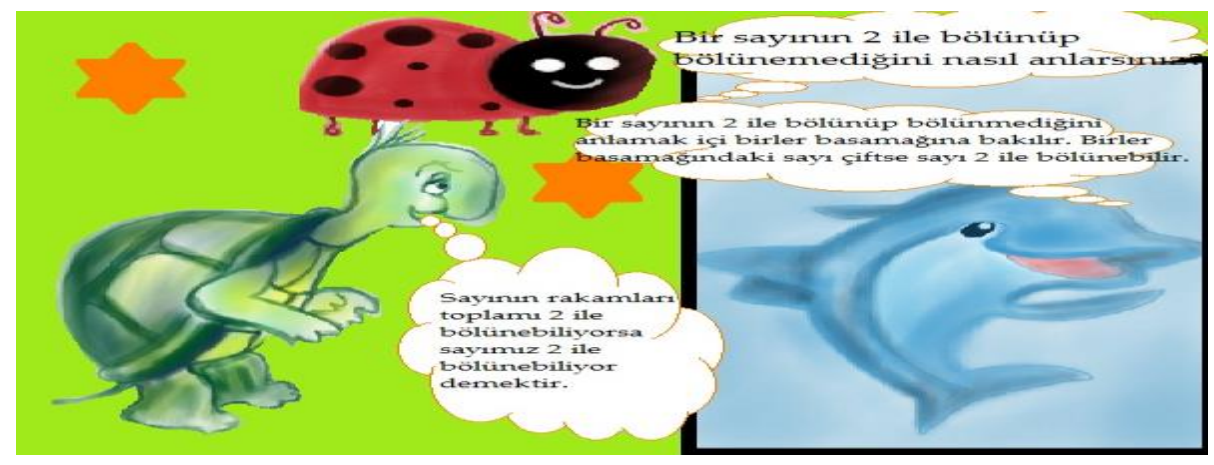

Figure 2. Divisibility rule of a sample of cartoon

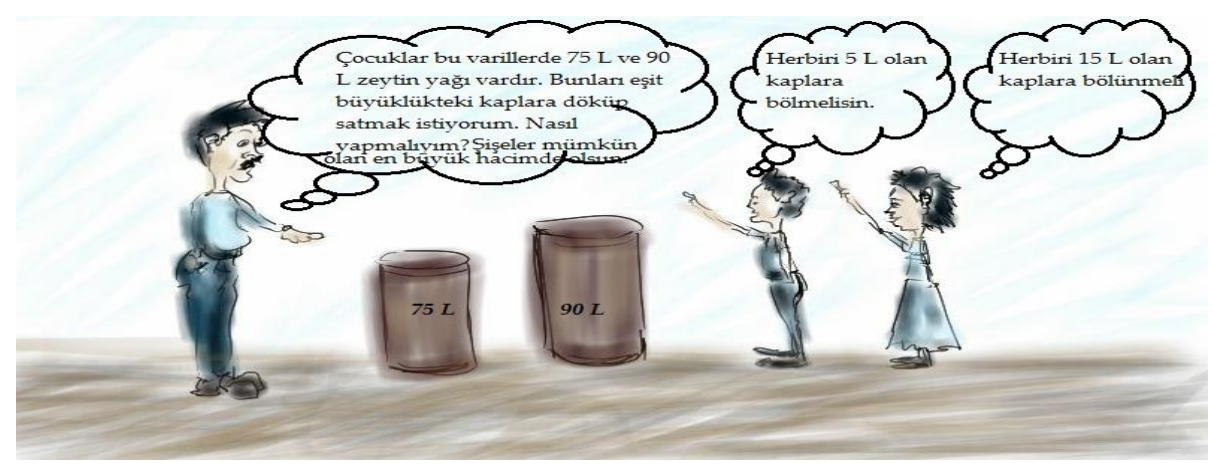

Figure 3. Divisibility and prime number a sample of cartoon 


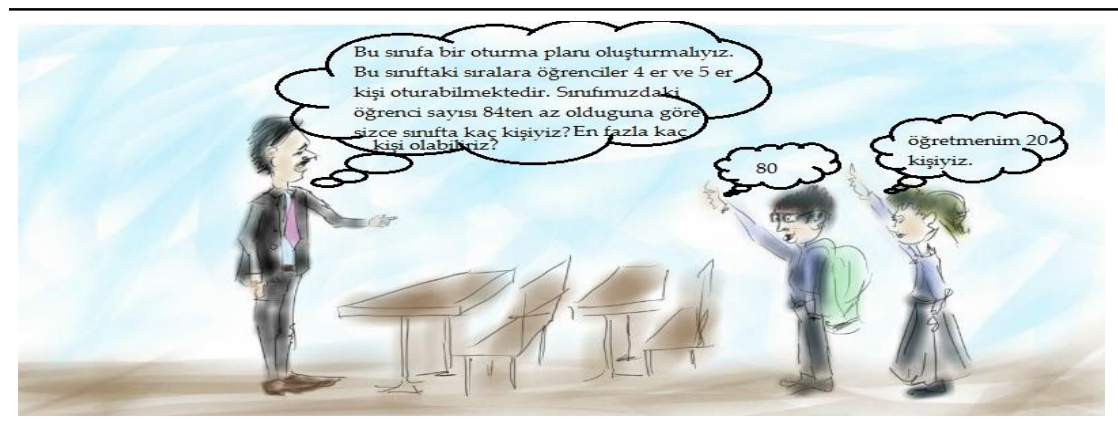

Figure 4. A sample of cartoon toward determined common factor of natural numbers

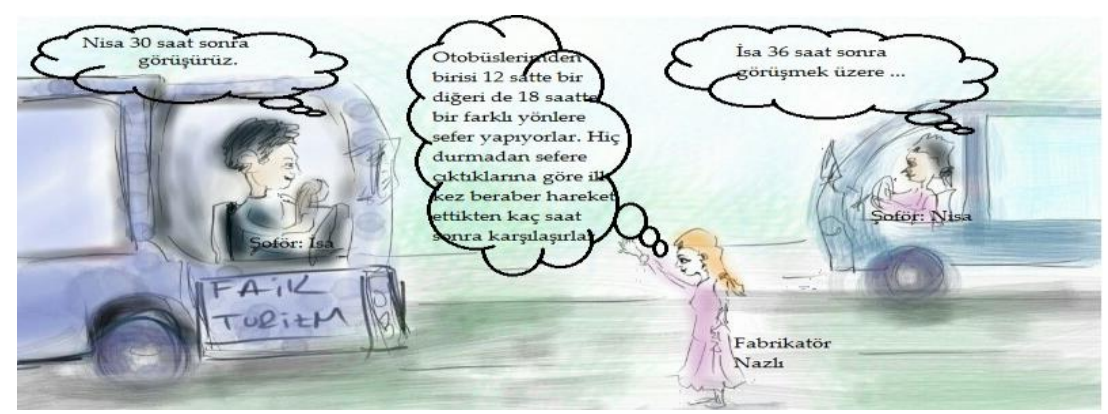

Figure 5. A sample of Cartoon Determined common divisor and common factors of natural number and applied problem

\section{Application of concept cartoon}

The group, experimental group that participated $(\mathrm{N}=22)$ students that applied concept cartoon, separate five groups. Two of these groups include five students, others ingredient four students. The groups form random selected method in student name list. Same cartoons distribute all the groups same process for example when a group studies divisibility rule with number 2, another group study, divisibility rule with number 3 , as well. The characters that represent the image of the thinking have been taken into consideration while preparing the comics. In addition to this, formed descriptions that represent the reality have not been thought as an abstract from the reality. Comics that include the turtles, ladybug and dolphin have been designed to attract the children. In other comics, facial expressions have been drawn as similar with the others in order to prevent the situations that push back the others. After preparation of the comics two teachers have examined these comics and it has been determined that characters are appropriate for above specified feature or not. Two mathematics teachers and two faculty members' opinions have been taken in order to determine the achievements related to the square root of the comics and then, necessary corrections have been made and it has been found to be appropriate. In addition, Turkish teachers' opinion has been taken in order to determine whether it is appropriate for children or not and it has been prepared in accordance to the level that children can understand. A cartoon prepared for ever objectives. After distributed cartoons to groups wanted controversy between students say of different characters and then supplied arrive right response with some clues and desired compared to right response and own responses and think about right response. Assessment of knowledge is made by this method.

\section{RESULTS}

Kolmogorov-Smirnov $\mathrm{Z}$ test is applied which will use test to make firm in the analysis of the data in this study that is whether parametric test use or not. Check 
whether normal distribution or not of the data by this test. In accordance with results of test the data suitable normal distribution ( $p>.05)$. Results of the test of the normality are appeared in Table 3.

Parametric hypothesis tests are used to the data suitable normal distribution. Collected data as pretests is analyzed independent t-test and found there wasn't significant difference $(p>05)$. Results of t- test for pretests are appeared in Table 4 .

Despite of there wasn't significant difference between pretests; there was difference mean point of pretests, therefore covariate the results of pretest used ANCOVA test. The test of homogeneity of variance is applied and in outcomes of test appeared that variance distribute as homogeneity $(p>.05)$. Examine slope of dependent variable and co-variable whether same line or not enough and there wasn't significant difference as statistical ( $p>.05)$. The results of posttest, ANCOVA, are appeared in Table 5.

There was significant difference between academic achievement posttest points of groups in the results of covariance analysis $[F(1,39)=6.178 ; p=.017<.05]$. There is no significant difference in academic performance of students who were taught divisibility rules and prime numbers and those who were taught the same topic by activity based instruction. Descriptive statistic for the means of corrected posttests point of groups is appeared in Table 6.

Examined means of posttest points of groups is appeared means of point of experimental group is $(\bar{x}=44.88)$, means of point of control group is $(\bar{x}=33.89)$. Using of multi compared tests have been needn't because there are only two groups. Significant difference, forming the result of ANCOVA, is favors experimental group

Table 3. The results of the test of the normality for pretest and posttest of experimental and control groups with Kolmogorov-Smirnov Z Test

\begin{tabular}{llcc}
\hline Groups & Tests & Kolmogorov- Smirnov (Ks-Z) & Significant Level (p) \\
\hline Experimental & Pre test & 1.065 & 0.207 \\
& Post test & 1.066 & 0.206 \\
Control & Pre test & 1.342 & 0.055 \\
& Post test & 1.577 & 0.054 \\
\hline
\end{tabular}

Table 4. The result of independent t- test for pre tests

\begin{tabular}{lccccccc}
\hline Groups & N & X & sd & df & t & p & Significant \\
\hline Experimental & 22 & 23.42 & 9.092 & 23.289 & 1.130 & 0.270 & No \\
Control & 20 & 30.28 & 25.725 & & & & \\
\hline
\end{tabular}

Table 5. The results of academic achievement posttest, ANCOVA, of groups

\begin{tabular}{lccccc}
\hline Variance Source & Sum of Squared & $\begin{array}{c}\text { Degrees of } \\
\text { Freedom }\end{array}$ & Mean Square & F & $\begin{array}{c}\text { Significant Level } \\
\text { (p) }\end{array}$ \\
\hline Corrected Model & 1346.229 & 2 & 673.115 & 3.399 & 0.044 \\
Intercept & 21973.196 & 1 & 21973.196 & 110.955 & 0.000 \\
Pre test & 20.336 & 1 & 20.336 & 0.103 & 0.750 \\
Group & 1223.441 & 1 & 1223.441 & 6.178 & 0.017 \\
Error & 7723.414 & 39 & 198.036 & & \\
Total & 75075.000 & 42 & & & \\
Corrected Total & 9069.643 & 41 & & & \\
\hline
\end{tabular}

Table 6. Descriptive statistic for the means of academic achievement posttest corrected points of groups

\begin{tabular}{|c|c|c|c|}
\hline Groups & $\begin{array}{l}\text { The number of } \\
\text { Students (N) }\end{array}$ & Means $(\overline{\mathbf{x}})$ & Standard Deviation (sd) \\
\hline Experimental & 22 & 44.88 & 3.03 \\
\hline Control & 20 & 33.89 & 3.18 \\
\hline
\end{tabular}


because mean of corrected points of experimental group is higher than mean of corrected points of control group.

\section{CONCLUSION}

Mathematics accordance to traditional teaching approach is knowledge uninterested from one another, far away to daily life, different to understand, with abstract principal and rule, constituted from difficult instruction equation and formulas an occupation. These specifications of math make it charmless and have to carry instruction to heart it. But math is most nearly daily life that is realize an abstract concept is considered as concrete (Baki, 2006). Activity and materials which interested of students gets charm for student this lesson. In accordance with this view on important, lead to new views in educational approaches, determine to effect on instruction of concept cartoon.

The effect of the concept cartoon and activity-based teaching on the academic achievement has been investigated with the covariance analysis between groups. Independent variables concept cartoons and activity-based teaching are academic achievement in the dependent variables. There is no meaningful difference between the averages of pre-test academic achievement grade on the participants. It has been found that the data have normally distributed, variances have homogeneously distributed and the regression curve has normally distributed before the analysis in the pre-control. It has been found that there is a meaningful difference between the averages of last test grade as a result of variance analysis test $[F(1.39)=6.178, p=$ $.017>.05]$. According to the adjusted average grades, it can be said that this difference is in favor of concept cartoon and group. It has been concluded that to use of concept cartoon in the teaching of 6th grade prime numbers and divisibility affects the academic achievement positively.

Accordance to finding in this study is instruction by concept cartoon significant degree as statistical more successful than activity based teaching. Similar to this result with results of some studies made prior to this (Dereli, 2008; Kaplan, Altayll, \& Öztürk, 2014; Sexton, Gervasoni, \& Brandenburg, 2009; Şengül \& Dereli, 2013; Üner, 2009). In spite of this study some study show that while concept cartoon compare to other instruction methods in mathematics education, it isn't more than affective other instruction methods (Güler, Çakmak, \& Kavak, 2013; Korucu, 2009). As well as made different studies are appear that used in mathematics education of concept cartoon evolve interest toward math of students and decreased anxiety toward math (Dereli, 2008; Şengül, 2011).

There are some important points need conclusion used concept cartoons in educational process. Initiate must discuss whether use or not by ever teacher of concept cartoon and how need prepared for use by all teachers of this cartoons. In addition to if must prepare own of teachers or must prepared cooperation interdisciplinary that is consider developed of math teachers draw by art teachers or computer teachers. When examined on math curriculum of primary school and middle school appeared that almost all subjects are concretive and can use whole as well. We think that concept cartoons are applied a lot of subjects which math course in high school, but must determine which grade degree more effective it.

\section{RECOMMENDATION}

This study contributes to teacher how instruction of the topic on divisibility rules and prime number for include material with this topic in this grade degree, so concept cartoon is hereby recommended for the teaching of the topics, divisibility rules and prime numbers among the sixth grade students, but this study have some limited which is the low of participant, prepared cartoons only number enough and 
only made six grade degree. Researchers must study more extensive sample and more excessive topic and concept cartoons is talked more excess teachers.

\section{AUTHORS' NOTE}

A part of this study is offered as verbal at "12. Matematik Sempozyumu".

\section{REFERENCES}

Akamca, G. Ö., Ellez, A. M. \& Hamurcu, H. (2009). Effects of computer aided concept cartoons on learning outcomes. Procedia Social and Behavioral Sciences, 1(1), 296-301.

Altun, M. (2008). İlköğretim ikinci kademede (6, 7 ve 8. sinıflarda) matematik öğretimi (5. Baskl). Bursa: Aktüel Alfa Akademi.

Aydın, G. (2015). The Effects of Computer-Aided Concept Cartoons and Outdoor Science Activities on Light Pollution. International Electronic Journal of Elementary Education, $7(2), 142-156$.

Baki, A. (2006). Kuramdan uygulamaya matematik egitimi. Trabzon: Derya Printing.

Balım, A., İnel, D. \& Evrekli, E. (2008). Fen öğretiminde kavram karikatürü kullanımının öğrencilerin akademik başarılarına ve sorgulayıcı öğrenme becerileri algılarına etkisi [The Effects the Using of Concept Cartoons in Science Education on Students' Academic Achievements and Enquiry Learning Skill Perceptions]. İlköğretim Online, 7(1), 188202.

Birisci, S., Metin, M. \& Karakas, M. (2010). Pre-service elementary teachers' views on concept cartoons: A sample from Turkey. Middle-East Journal of Scientific Research, 5(2), 91-97.

Birisçi, S. \& Metin, M. (2010). Developing an instructional material using a concept cartoon adapted to the 5E Model: A sample of teaching erosion. Asia-Pacific Forum on Science Learning and Teaching, 11(1), 1-16.

Büyüköztürk, Ş., Kllıç-Çakmak, E., Akgün, Ö. E., Karadeniz, Ş. \& Demirel, F. (2010). Bilimsel araştırma yöntemleri (6. baskı). Ankara: Pegem Akademi yayınları.

Cengizhan, S. (2011). Prospective teachers' opinions about concept cartoons integrated with modular instructional design. Education and Science, 36(160), 93-104.

Corbetta, P. (2003). Social research theory, methods and techniques. London: Sage Publication.

Dereli, M. (2008). The effects of teaching the integers subject by cartoon to the students mathematical success. (Unpublished master thesis). Marmara University, İstanbul.

EARGED. (2005). PISA 2003 Projesi - Ulusal Nihai Rapor. Ankara: MEB Eğitimi Araştırma ve Geliștirme Dairesi Bașkanlığı.

EARGED. (2010a). PISA 2006 Projesi - Ulusal Nihai Rapor. Ankara: MEB Eğitimi Araștırma ve Geliştirme Dairesi Başkanlığı.

EARGED. (2010b). PISA 2009 Projesi - Ulusal Ön Rapor. Ankara: MEB Eğitimi Araştırma ve Geliştirme Dairesi Başkanlı̆̆g.

Eden, H. (2011). İlköğretim matematik 6 öğretmen kılavuz kitabı. İstanbul: Meram Yayıncılık.

Ekici, F., Ekici, E. \& Aydın, F. (2007). Utility of concept cartoons in diagnosing and overcoming misconceptions related to photosynthesis. International Journal of Environmental \& Science Education, 2(4), 111-124.

Göğün, Y. (2010). Illköğretim matematik 6. sinıf öğretmen kılavuz kitabı. Ankara: Özgün Matbaacllık Sanayii ve Ticaret Anonim Şirketi.

Güler, H. K., Çakmak, D. \& Kavak, N. (2013). Karikatürlerle yapılan matematik öğretiminin öğrencilerin akademik başarılarına ve tutumlarına etkisi [Effects on mathematics teaching with cartoons on student's academic achievement and attitudes]. Uludağ Üniversitesi Eğitim Fakültesi Dergisi, 26(1), 149-160.

İnel, D., Balım, A. G. \& Evrekli, E. (2009). Fen öğretiminde kavram karikatürü kullanımına ilişkin öğrenci görüşleri [The opinions of students about the use of concept cartoon in science and technology education]. Necatibey Eğitim Fakültesi Elektronik Fen ve Matematik Ĕgitimi Dergisi, 3(1), 1-16.

Kabapınar, F. (2009). What makes concept cartoons more effective? Using research to inform practice. Education and Science, 34(154), 104-118.

Kaplan, A., Altaylı, D. \& Öztürk, M. (2014). Kareköklü sayılarda karşılaşılan kavram yanılgılarının kavram karikatürü kullanılarak giderilmesi [Removing the 
misconceptions met in root numbers by concept cartoons]. Uludağ Üniversitesi Eğitim Fakültesi Dergisi, 27(1), 85-102.

Kaplan, A., İşleyen, T. \& Öztürk, M. (2011). 6. sınıf oran orantı konusundaki kavram yanılgiları [The misconceptions in ratio and proportion concept among $6^{\text {th }}$ grade students]. Kastamonu Eğitim Dergisi, 19(3), 953-968.

Kaplan, A., Öztürk, M. \& Ertör, E. (2013). The efficiency of computer- aided instruction and creative drama on academic achievement in teaching of integers to seventh grade students. International Journal of Academic Research Part: B Social and Educational Studies, 5(2), 49-56. doi:10.7813/2075-4124.2013/5-2/B.7

Karamustafaoglu, O. (2009). Active learning strategies in physics teaching. Energy Education Science and Technology Part:B Social and Educational Studies, 1(1), 27-50.

Kayıș, A. (2009). Güvenilirlik analizi. In Ș. Kalaycı (Ed.), SPSS Uygulamalı çok değişsenli istatistik teknikleri (pp. 404-406). Ankara: Asil Yayın Dağıtım Ltd. Şti.

Keogh, B., Naylor, S., Boo, M. \& Feasey, R. (2002). Formative assessment using concept cartoons: initial teacher training in the UK. In H. Behrendt, H. Dahncke, R. Duit, W. Gräber, M. Komorek, A. Kross \& P. Reiska (Eds.), Research in science education-past, present and future (pp. 137- 142). Netherlands: Kluwer Acad.

Korucu, S. (2009). Comparison of cartoons and computer-assisted teaching methods on polygons. İstanbul: Marmara University.

McMillan, J. W. \& Schumacher, S. (2014). Research in education: Evidence-based inquiry (Seventh Edition). Boston: Pearson.

Morris, M., Merritt, M., Fairclough, S., Birrell, N. \& Howitt, C. (2007). Trialling concept cartoons in early childhood teaching and learning of science. Teaching Science, 53(2), $42-45$.

Naylor, S. \& Keogh, B. (1999). Constructivism in classroom: Theory into practice. Journal of Science Teacher Education, 10(2), 93-106.

Ormancı, Ü. \& Şaşmaz-Ören, F. (2011). Assessment of concept cartoons: An exemplary study on scoring. Procedia Social and Behavioral Sciences, 15, 3382-3589.

Sewell, A. (2002). Constructivism and student misconceptions. Australian Science Teachers Journal, 48(4), 24-28.

Sexton, M., Gervasoni, A. \& Brandenburg, R. (2009). Using a concept cartoon to gain insight into children's calculation strategies. Australian Primary Mathematics Classroom, 14(4), 24-28.

Stephenson, P. \& Warwick, P. (2002). Using concept cartoons to support progression in students' understanding of light. Physics Education, 37(2), 135-141.

Şahin, C.. \& Çepni, S. (2011). Developing of the Concept Cartoon, Animation and Diagnostic Branched Tree Supported Conceptual Change Text: "Gas Pressure". Eurasian Journal of Physics and Chemistry Education, [Special Issue], 25-33. from www.eurasianjournals.com

Şengül, S. (2011). Kavram karikatürlerinin 7. sınıf öğrencilerin matematiksel öz-yeterlik düzeylerine olan etkisi [Effects of concept cartoons on mathematics self-efficacy of 7th grade students]. Kuram ve Uygulamada Eğitim Bilimleri, 11 (4), 2291-2313.

Şengül, S. \& Dereli, M. (2013). The effect of learning integers using cartoons on 7 th grade students' attitudes to mathematics. Educational Sciences: Theory \& Practice, 13(4), 2509-2534.

Şengül, S. \& Üner, İ. (2010). What is the impact of the teaching "Algebraic expression and equations" topic with concept cartoons on the students' logical thinking abilities. Procedia Social and Behavioral Sciences, 2(2), 5441-5445.

Uğurel, I. \& Moralı, S. (2006). Karikatürler ve matematik öğretiminde kullanımı. [Cartoons and their use in mathematics]. Milli Eğitim Dergisi, 170, 32-47.

Üner, İ. (2009). The effects of learning via cartoons on students' success and attitude levels in primary schools. (Unpublished master thesis). Marmara University, İstanbul.

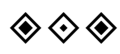

